\title{
Temporal and spatial dynamics in large rivers : example of a long-term monitoring of the middle Rhône River
}

\author{
J.-F. Fruget ${ }^{1,2 *}$ \\ M. Centofanti ${ }^{1,2}$ \\ J. Dessaix ${ }^{1,2}$ \\ J.-M. Olivier ${ }^{2}$ \\ J.-C. Druart ${ }^{3}$ \\ P.-J. Martine $z^{4}$
}

Keywords : long-term monitoring, large river, Rhône River, physico-chemistry, periphyton, phytoplankton, macroinvertebrates, fish.

In running water, the main natural factor of disturbance is hydraulic. Investigation of its biological impact is currently complicated by the increase of anthropogenic disturbances which tend to mask the natural functioning of rivers. Monitoring of the impacts of the artificial alterations undergone by the Middle Rhône River for some decades took place in the mid-1980s. Discharge and temperature could constitute the major events controlling the biological dynamics in terms of variations in species richness, diversity, and abundance. The between-years changes of the structure and diversity of macroinvertebrate communities were connected with the amplitude of discharge fluctuations. This was in accordance with the disturbance-diversity concept and it seems to confirm the intermediate disturbance hypothesis. The fish community mainly depended on hydroclimatic factors that influenced breeding success. Variations in nutrient input played a secondary role in controlling changes in some communities (particularly the periphyton). Therefore it appears that the study of long-term changes in river systems, including the dynamics of their biological communities, requires continuous observations and data collection that only medium- to longterm studies can provide, implying the setting up of ecological monitoring centres for the natural environment such as the Long Term Ecological Research (LTER) sites in United States.

Dynamique spatio-temporelle dans les grands cours d'eau : exemple du suivi à long terme du Rhône Moyen (France)

Mots-clés : suivi à long terme, grand cours d'eau, Rhône, physico-chimie, périphyton, phytoplancton, macroinvertébrés, poissons.

En eau courante, le principal facteur naturel de perturbation est d'ordre hydraulique. A l'heure actuelle, ce problème se trouve particulièrement compliqué par l'accroissement des perturbations anthropiques qui tendent à masquer le fonctionnement naturel des cours d'eau. Un suivi des impacts des perturbations anthropiques subies depuis plusieurs décennies par le Rhône Moyen a été mis en place au milieu des années 80 . L'hydrologie et la température semblent les principaux événements régissant la dynamique biologique en terme de variation de la richesse spécifique, de la diversité et de l'abondance des différentes espèces. Les variations inter-annuelles de la structure et de la diversité des peuplements de macoinvertébrés sont ainsi liées à l'amplitude des fluctuations de débit. Ceci est tout à fait en accord avec le concept de perturbation-diversité et la théorie des perturbations moyennes. Pour sa part, le peuplement piscicole dépend des facteurs hydroclimatiques pour le succès de la reproduction. En second lieu, la dynamique des apports nutritifs gouverne également l'évolution de certains peuplements (en particulier le périphyton). Dans ce cadre, l'étude de l'évolution des hydrosystèmes fluviaux et de la dynamique de leurs peuplements impliquent une continuité d'observation et de récolte de données que seule permet une surveillance à moyen ou long terme, nécessitant la mise en place de véritables observatoires écologiques du milieu naturel, tels que les sites du programme LTER (Long Term Ecological Research) aux Etats-Unis.

\footnotetext{
1. ARALEPBP, Ecologie des Eaux Douces, Université Lyon 1, Bât. 403, 69622 Villeurbanne cedex, France.

2. UMR CNRS 5023 "Ecologie des Hydrosystèmes Fluviaux", Université Lyon 1, 69622 Villeurbanne cedex, France.

3. INRA, Institut de Limnologie, Station d'Hydrobiologie lacustre, B.P. 511, 74203 Thonon-les-Bains cedex, France.

4. GREBE, Eau-Sol-Environnement, 23 rue Saint-Michel, 69007 Lyon, France.

* Corresponding author. E-mail : jean-francois.fruget@univ-lyon1.fr
} 


\section{Introduction}

The concept of variability, as well of environments as of communities, is essential in the study of ecosystem dynamics. It includes the concepts of refugia (space variability) and disturbance (temporal variability) (Connell 1978, Ward \& Stanford 1983, Townsend 1989). Within this framework, the ecosystem dynamics are under the double influence of environmental factors (seasonal cycles, e.g.) and unpredictable events (disturbances) (Pickett et al. 1989). In running water, the main factor of disturbance is hydraulic (Statzner \& Higler 1986) : floods and low waters constitute critical phases of which the effects depend as much on the intensity of disturbance as on the date on which it occurs. Indeed, according to the biological characteristics of the communities (life-history traits), that which constitutes a disturbance for some can be an opportunity for others.

Most of the world's large rivers are greatly affected by human activities (Petts et al. 1989, Dynesius \& Nilsson 1994). Biological monitoring or environmental impact assessment programmes of regulation schemes provide large data sets which increase our understanding of the functioning of these modified systems (Johnson et al. 1995). Power production is the main reason for river regulation in France (Khalanski \& Gras 1996). The Middle Rhône, a part of the river situated between Lyon and the confluence of the Isère (Fig. 1 A), has been greatly altered for nearly 200 years. Embankments were built in the 19th century for flood control and navigation improvement, and in more recent times came hydroelectric schemes and canalization by the Compagnie Nationale du Rhône (CNR), and use of the river for cooling nuclear and thermal electricity generating plants by Electricité de France (EDF) (Fruget 1992). In addition to the physical changes, the growth of cities such as Lyon and the installation of major petrochemical complexes have changed the chemical composition of Rhône water.

The way in which the biological communities answer these constraints (adaptation, resilience, resistance, etc), as well in space as in time, is very important in terms of bioevaluation and management of ecosystems and species. A monitoring of the impacts of these changes took place in the mid-1980s on the Middle Rhône. Previous studies were interested in the impact of regulation on the Lower Rhône as a whole (Fruget 1992), in the impact on the invertebrates more particularly (Fruget 1991) or in the influence or not of the warmed water discharge of St-Alban power plant (Fruget et al. 1999). The main question investigated in this paper is : which are the main factors controlling the biological dynamics and variability during the first ten years of this monitoring ? Have they a temporal and/or a spatial character?

Various abiotic and biotic variables were used as measuring tools (descriptors in the sense of Bournaud \& Amoros 1984) : the physico-chemistry of the water, an abiotic descriptor, and several biological integrative indicators, such as the phytoplankton and periphyton algae, benthic invertebrates and the fish fauna, were thus measured at regular intervals.

\section{Materials and methods}

\subsection{Study area}

The Péage-de-Roussillon area is located on the Middle Rhône about $50 \mathrm{~km}$ downstream of the city of Lyon (Fig. 1A). Alterations undergone by this part of the Rhône River were triple : chemical, physical and hydraulic. This reach of the river receives much discharge of domestic and industrial effluents, particularly ammonium and phosphates originating from industries situated upstream (Fruget 1992). A hydroelectric scheme involving bypassing part of the river flow was built in 1977, and a nuclear power plant located near the reservoir above the dam began operating in 1985.

In its natural state, the river had an extensive network of braided channels (Michelot 1983, Fruget \& Michelot 1997). The construction of flood dykes in the last century, and then other works by the CNR constrained these river dynamics. The area does however still have well preserved riparian forests and several dead arms forming one of the last complexes of natural habitats downstream from Lyon. But a large proportion of these habitats are confined between the diversion canal and the former river channel. In addition to the natural environments (i.e. functional units) defined as processes of ecological succession (dead arms, the by-passed river course), engineering works created more or less artificial units such as the reservoir above the dam and the diversion canal.

The old river bed (called the by-passed section) is now closed by a dam and only receives a small residual flow (10 to $20 \mathrm{~m}^{3} \mathrm{~s}^{-1}$, out of a total average discharge of about $1030 \mathrm{~m}^{3} \mathrm{~s}^{-1}$ ) except in periods of floods.

Five sampling stations were chosen for this study. They were located in various environments and habitat types (Fig. 1B) : the reservoir upstream and downstream from St-Alban power plant (stations 1 and 2), the diversion canal (station 3 , in the tailrace channel), 


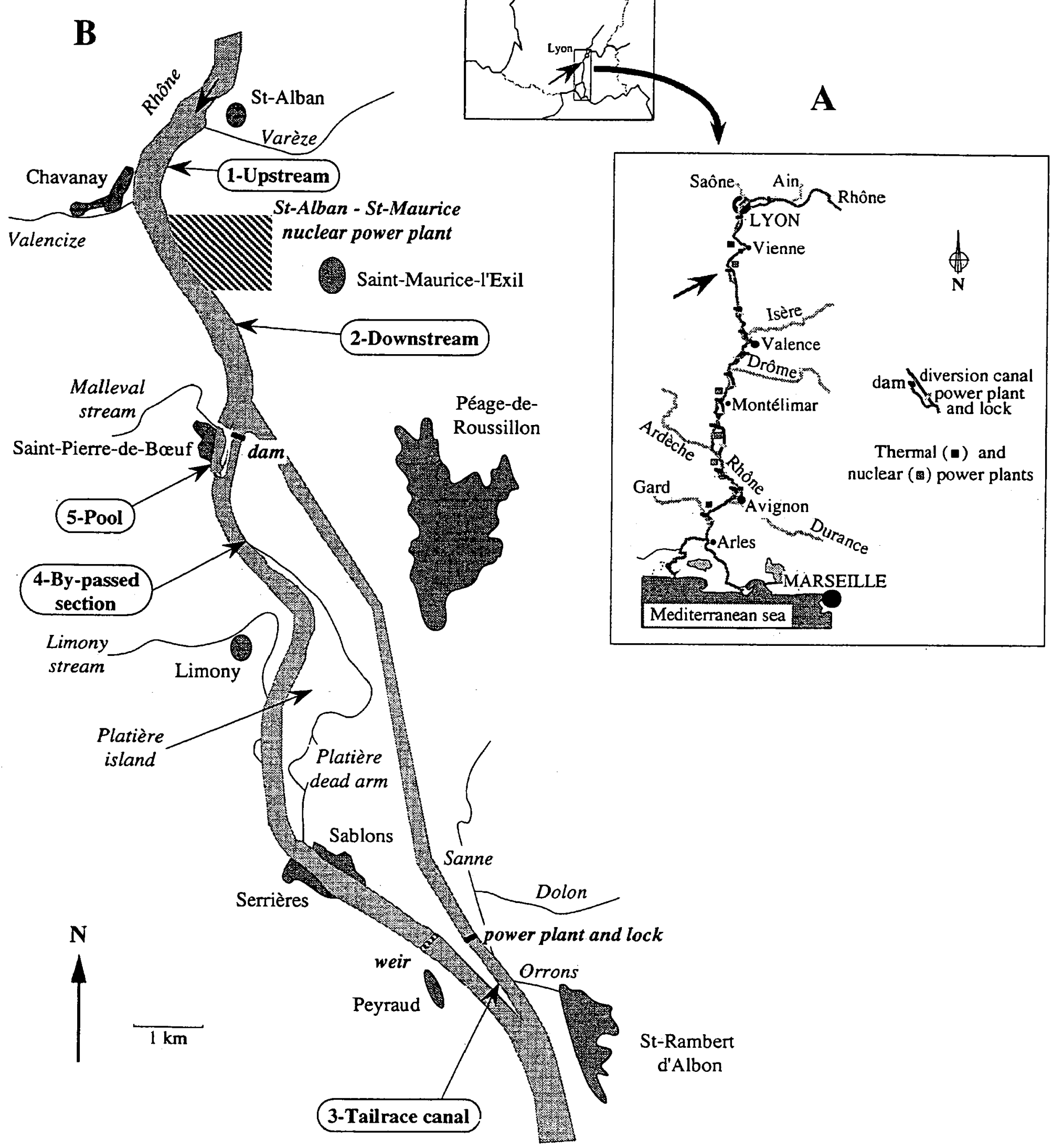

Fig. 1. Study area. (A) Regulation of the Lower Rhône River. (B) Location of the sampling stations in the Péage-de-Roussillon development scheme.

Fig. 1. Site d'étude. (A) Aménagement général du Bas-Rhône. (B) Localisation des stations de prélèvement au niveau de l'aménagement de Péage-de-Roussillon. 
the bypassed former Rhône channel (station 4, in an embanked section with a slower current) and a pool in the former river channel bypassed by the construction of the dam flood spillway (station 5). At stations 1,2 and 3 the shorelines are embanked by boulders (riprap) whereas at stations 4 and 5 they are more diverse and natural. Substratum is coarse (stones, pebbles and gravel) in the river channel at stations 3 and 4 and it is fine (silt and mud) in the reservoir and the pool.

\subsection{Field measurements and laboratory analyses}

Physico-chemical survey was made by spot analyses of 20 "standard" physico-chemical water quality variables (temperature, conductivity, $\mathrm{pH}$, dissolved oxygen, concentrations of inorganic and organic substances, chlorophyll a). The first four parameters were measured in situ with WTW conducti-, oxy- and $\mathrm{pH}$ meters. Inorganic substances ( $N, P$, etc.) were mainly analysed by ionic chromatography by an expert laboratory. Chemical oxidation and purple-ultra detection were used for Total Organic Carbon. Chlorophyll a content was estimated spectrophotometrically after filtration and extraction in acetone according to Lorenzen's method (1967) and calculation according to Parsons \& Strickland's equations (1963).

Phytoplankton samples were collected by towing a net of $60 \mu \mathrm{m}$ mesh size in the middle of the channel of the different water bodies investigated so as to collect a sample of about $100 \mathrm{ml}$. This sample was fixed with $4 \%$ formalin and preserved for species identification. This sampling method explains why the results are strictly qualitative. The periphyton was collected by scraping an area of sediment (gravel or stones) or plant debris (dead branches) in a fixing fluid of formaldehyde and acetic acid (approximately a $500 \mathrm{~cm}^{3}$ box of sediment or branches). Species composition of all groups of algae was then determined. These algae were only studied at 4 stations, station 3 (located in the tailrace) being excluded because of the wide variation in water depth caused by the operation of the Sablons hydrolelectric station. Results were expressed in presence-absence for the phytoplankton and in abundance classes for the periphyton.

Two complementary methods were used to sample the benthic macrofauna in various habitats : artificial substrates (plastic netting filled with $20 \mathrm{~m}$ of sisal string and some pebbles) were installed close to the river margins and dredgings were performed in the deeper parts of the channel with an oceanic-type cylindrical dredge (Reys \& Salvat 1971) or an Irish-type triangular one (Elliott et al. 1980) according to particle size of the bottom substratum and water depth. In situ, arti- ficial substrata or sediment and associated organisms were stored in a box and preserved in $4 \%$ formalin. In the laboratory, the invertebrates were sorted, preserved in $70 \%$ ethanol, identified to species level if possible (except Oligochaeta and Diptera, not identified beyond family level) and counted to calculate different community parameters (taxonomic richness, relative abundance, diversity index, etc.).

Fish fauna was sampled by electric fishing using the EPA method (Nelva et al. 1979, Persat \& Copp 1990, Persat \& Olivier 1991) which, in addition to providing a description of the fish fauna, also gives a multi-point habitat description by recording some habitat variables.

All these data were collected seasonally (4 to 5 sampling dates per year) starting in 1985, or in 1982-83 for some of them (e.g. physico-chemistry and invertebrates). The study period considered in this paper ended in 1994.

\subsection{Data analysis}

With the exception of those concerning the fish fauna, the data matrices were submitted to betweenclasses and within-classes statistical analyses (Principal Components Analysis and Correspondence Analysis) (Dolédec \& Chessel 1989) which take into account, or else eliminate, some effects related to the experimental process, such as distinguishing between seasonal and environmental effects within data, for example. Decentred Correspondence Analysis (Dolédec et al. 1995) was used to analyze the electric fishing data. This method is well adapted for analyzing the structure of the ichthyofauna collected with the point abundance sampling technique because it takes into account the sampling effort, i.e. the number of point samples per fishing campaign. All the analyses and plotting of graphs were performed using ADE-4 software (Thioulouse et al. 1997).

Some transformations were done in some data matrices before previous calculations. For example, chemical data (224 samples x 20 variables) were normalized as is usual for variables with different units. Concerning the invertebrates, "rare" taxa were discarded according to the abundance criterion (globally $\leq 2$ individuals) or the occurrence criterion (presence in $\leq$ 2 samples). Data (456 samples, each one of 1 station, 1 sampling technique, 1 date ; 107 taxa) were expressed in $\log 2$, which allowed to standardize the abundances. Fish species, collected in 198 samples (each one of 20 point samples at 1 station, 1 date) were divided into size classes (52 taxa, see Table 1). 
Table 1. Codes and subdivision into size classes and total occurrence and abundance of the main fish species.

Tableau 1. Codes et séparation en classes de tailles, occurrence et abondance totales pour les principales espèces de poissons.

\begin{tabular}{|c|c|c|c|c|c|}
\hline Common name & Species & Code & $\begin{array}{c}\text { Total length } \\
(\mathrm{cm})\end{array}$ & $\begin{array}{c}\text { Occurrence } \\
\text { ( } \mathrm{x} / 3960 \text { point } \\
\text { samples) }\end{array}$ & $\begin{array}{c}\text { A bundance } \\
\text { (number of } \\
\text { individuals) }\end{array}$ \\
\hline \multirow[t]{2}{*}{ Bleak } & Alburnus alburnus & $\begin{array}{l}\text { ABL1 } \\
\text { ABL2 }\end{array}$ & $\begin{array}{l}{[2-5[} \\
{[5-9[}\end{array}$ & $\begin{array}{l}107 \\
344\end{array}$ & $\begin{array}{c}986 \\
1790\end{array}$ \\
\hline & & ABL3 & {$[9-17[$} & 275 & 1130 \\
\hline \multirow[t]{3}{*}{ Barbel } & Barbus barbus & BAF1 & {$[2.5-7[$} & 73 & 127 \\
\hline & & BAF2 & {$[7-24[$} & 38 & 61 \\
\hline & & BAF3 & {$[24-50[$} & 8 & 9 \\
\hline \multirow[t]{5}{*}{ White bream } & Blicca bjoerkna & $\mathrm{BRB} 1$ & {$[1.7-3[$} & 30 & 70 \\
\hline & & BRB2 & {$[3-7[$} & 213 & 1020 \\
\hline & & BRB3 & {$[7-11[$} & 190 & 882 \\
\hline & & BRB4 & {$[11-17[$} & 171 & 684 \\
\hline & & BRB5 & {$[17-40[$} & 104 & 200 \\
\hline \multirow[t]{3}{*}{ Bream } & Abramis brama & BRE1 & {$[2.5-4[$} & 12 & 39 \\
\hline & & BRE2 & {$[4-17[$} & 76 & 245 \\
\hline & & BRE3 & {$[17-61[$} & 32 & 45 \\
\hline \multirow[t]{5}{*}{ Chub } & Leuciscus cephalus & CHE1 & {$[1.5-6[$} & 384 & 1354 \\
\hline & & CHE2 & {$[6-11[$} & 419 & 877 \\
\hline & & CHE3 & {$[11-23[$} & 657 & 1246 \\
\hline & & $\mathrm{CHE} 4$ & {$[23-36[$} & 650 & 1166 \\
\hline & & CHE5 & {$[36-63[$} & 530 & 874 \\
\hline \multirow[t]{4}{*}{ Roach } & Rutilus rutilus & GAR1 & {$[2-5[$} & 295 & 1579 \\
\hline & & GAR2 & {$[5-11[$} & 1108 & 8007 \\
\hline & & GAR3 & {$[11-20[$} & 672 & 2605 \\
\hline & & GAR4 & {$[20-37[$} & 354 & 703 \\
\hline \multirow[t]{2}{*}{ Gudgeon } & Gobio gobio & GOU1 & {$[1.5-8[$} & 170 & 405 \\
\hline & & GOU2 & {$[8-17[$} & 72 & 112 \\
\hline \multirow[t]{5}{*}{ Nase } & Chondrostoma nasus & HOT1 & {$[1.9-6[$} & 32 & 52 \\
\hline & & HOT2 & {$[6-10[$} & 36 & 145 \\
\hline & & НОT3 & {$[10-17[$} & 26 & 60 \\
\hline & & HOT4 & {$[17-37[$} & 50 & 80 \\
\hline & & HOT5 & {$[37-51[$} & 114 & 209 \\
\hline \multirow[t]{2}{*}{ Stone loach } & Noemacheilus barbatulus & LOF1 & {$[1.9-5[$} & 23 & 36 \\
\hline & & LOF2 & {$[5-11[$} & 65 & 93 \\
\hline \multirow[t]{3}{*}{ Black bullhead } & Ictalurus melas & $\mathrm{PCH} 1$ & {$[2.5-6[$} & 41 & 145 \\
\hline & & $\mathrm{PCH} 2$ & {$[6-13[$} & 57 & 161 \\
\hline & & PCH3 & {$[13-29[$} & 127 & 178 \\
\hline \multirow[t]{2}{*}{ Perch } & Perca fluviatilis & PER1 & {$[2.2-15[$} & 166 & 273 \\
\hline & & PER2 & {$[15=37[$} & 148 & 170 \\
\hline \multirow[t]{3}{*}{ Pumpkinseed } & Lepomis gibbosus & PES1 & {$[1-6[$} & 307 & 768 \\
\hline & & PES2 & {$[6-12[$} & 715 & 1495 \\
\hline & & PES3 & {$[12-24[$} & 623 & 961 \\
\hline \multirow[t]{3}{*}{ Rudd } & Scardinius erythrophtalmus & ROT1 & {$[2.3-9[$} & 93 & 219 \\
\hline & & ROT2 & {$[9-19[$} & 50 & 70 \\
\hline & & ROT3 & {$[19-37[$} & 52 & 65 \\
\hline \multirow[t]{2}{*}{ Pike-perch } & Stizostedion lucioperca & SAN1 & {$[3-6[$} & 11 & 20 \\
\hline & & SAN2 & {$[6-61[$} & 37 & 39 \\
\hline \multirow[t]{3}{*}{ Tench } & Tinca tinca & TAN1 & {$[1.5-11[$} & 166 & 271 \\
\hline & & TAN2 & {$[11-23[$} & 80 & 85 \\
\hline & & TAN3 & {$[23-49[$} & 108 & 133 \\
\hline
\end{tabular}


Detailed biological results concerning community structures and species compositions may be found in Fruget et al. (1999).

\section{Results}

\subsection{Hydrological and thermal conditions}

During the study period the Rhône discharge upstream of Péage-de-Roussillon hydroelectric scheme was much below average in 1989 (mean discharge $=$ $718 \mathrm{~m}^{3} \mathrm{~s}^{-1}$; relative discharge, i.e. yearly mean discharge to long-term mean discharge ratio, $=0.7$ ). This was a turning point marking the start of three dry years (Fig. 2). Minimum average daily discharge was $210 \mathrm{~m}^{3} \mathrm{~s}^{-1}$ in September 1985, i.e. below mean low flow discharge $\left(300 \mathrm{~m}^{3} \mathrm{~s}^{-1}\right)$. Maximum average daily discharge was $4450 \mathrm{~m}^{3} \mathrm{~s}^{-1}$ in February 1990, i.e. about that of a ten year return-time flood.

The mean annual water temperature of the Rhône immediately upstream from St-Alban power plant was $13.9^{\circ} \mathrm{C}$ for the reference period of $1988-1994$. Various thermal sequences were recorded during this period (Fig. 2) : 1988 to 1991 were years with higher than average mean annual temperatures $\left(\geq 14^{\circ} \mathrm{C}\right)$; then a decrease took place from 1991 to 1993 , when the temperature was lower than $13^{\circ} \mathrm{C}$; finally, 1994 was again a warm year with the highest mean monthly temperature of $24.5^{\circ} \mathrm{C}$ in July. Year 1989 had the highest mean annual temperature of $14.8^{\circ} \mathrm{C}$.

\subsection{Spatial vs temporal changes}

The first eigenvalue and the percentage of inertia of the various statistical analyses of the physico-chemical data showed that the date effect (seasons and years) was much greater than the station effect (Fig. 3A). If the first eigenvalue of the general PCA was taken as a reference, the within-classes analyses (which measure the loss of information compared to the reference) showed that this loss was greater for the within-dates and within-years analyses than for the within-stations analysis, whereas the between-classes analyses (which measure the gain in information) showed that the seasonal effect was greater than the station effect. This signifies that events such as hydrology (whose variations were correlated with the volume of inputs), or the discontinuation of some industrial outflows upstream from the sector were major physico-chemical events. Inversely, the statistical analyses of the macroinvertebrate data showed clearer spatial than either seasonal or between-years temporal differences (Fig. 3B). Habitat heterogeneity described by the station-technique analyses (bank or mid-channel, mud or stones accor- ding to the sampling techniques and the stations considered) was of fundamental importance in the case of the benthic fauna.

Because of the great number of data sets (cf. data analysis), all the graphical results of the previous analyses are not shown (see Fruget et al. 1999 for more detailed analyses), and according to the main question investigated (long-term variability) only the betweenyears analyses are discussed. The first axis of the between-years PCA of the physico-chemistry distinguished years 1993 and 1994 and the first year (1982-83) of the monitoring (samples factorial map). The position of this year 1982-83 is explained by a particularly high discharge (see Fig. 2) and consequently high contents of suspended matter and values of turbidity, for example. The first axis of the correlation circle of variables (Fig. 4A) distinguished oxydability and especially $\mathrm{NO}_{3}$ concentrations from other parameters $\left(\mathrm{BOD}_{5}, \mathrm{PO}_{4}\right.$, Chla, etc.). Three trends may be defined (Fig. 4B) : (1) a clear decrease in phosphate concentrations after 1992, that could be related to the closing of some industrial outflows ( 6 tons $P$ per day) at the end of 1992 ; (2) a fall in the chlorophylll concentrations starting in 1992 (subsequent to the high concentrations in the years of low river discharge that preceded it) ; (3) a more or less simultaneous increase in nitrate concentrations, involving a strong increase in the nitrate-to-phosphate ratio from a mean of about 3 in the period 1982-1992 to 20 or 30 in 1993 to 1994. Similarly, the second axis of the between-years correspondence analyses of the algae distinguished 1993 and 1994 from the other years in the case of phytoplankton and showed a sequential arrangement demonstrating a slow shift in the periphyton community during the study period (Fig. 4C \& 4D).

Despite the importance of spatial characteristics (habitat heterogeneity, see above), the between-years analysis of the macroinvertebrate fauna detected a temporal shift between 1985 and 1994 : the centre of each class (i.e. year) on the factorial map on one hand, and the coordinates of the F1 between-years analysis on the other hand, were on the positive part of the graphics for the 1980s and on the negative part for the 1990s (Fig. 5A). Because of the high uniformity of the fauna of the regulated Rhône (benthic communities were dominated by eurytopic and pollution-tolerant species ; see Fruget 1991, 1994), this difference could be explained by changes in environmental conditions : the abundance of some species could change concurrently with the variability of the hydrological and thermal conditions discussed previously. In fact, among the most abundant species ( 31 species with total abun- 


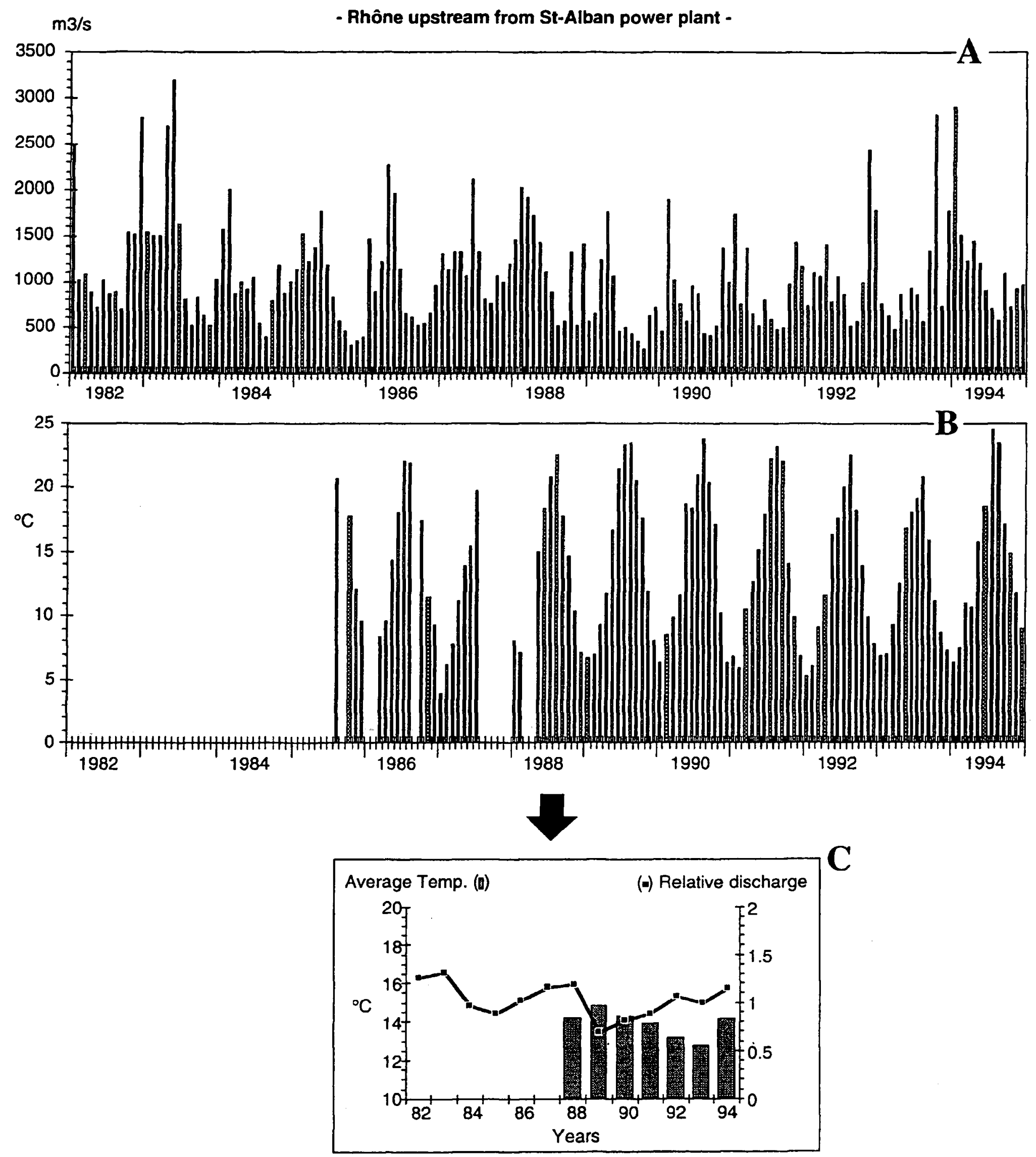

Fig. 2. Discharge and temperature of the Rhône River upstream from the study area. Average monthly discharge (A) and temperature (B) ; average yearly temperature and relative discharge coefficient (C).

Fig. 2. Débit et température du Rhône en amont du site d'étude. Valeurs moyennes mensuelles du débit (A) et de la température (B). Température moyenne et coefficient d'hydraulicité annuels (C). 


\begin{tabular}{|c|c|c|c|}
\hline & \multicolumn{3}{|c|}{$\begin{array}{l}\text { Total inertia of global } \\
P C A=20.0\end{array}$} \\
\hline Factor & Station & Season & Year \\
\hline between-classes PCA & 0.54 & 3.23 & 4.34 \\
\hline within-classes PCA & 19.46 & 16.77 & 15.66 \\
\hline
\end{tabular}

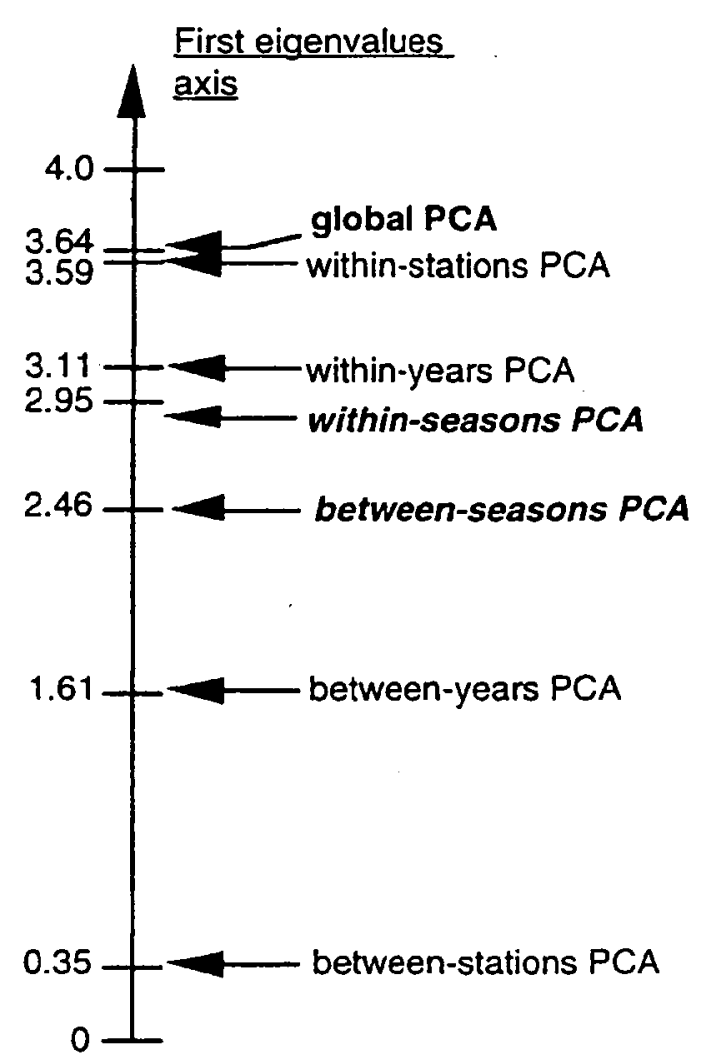

\begin{tabular}{|c|c|c|c|c|c|}
\hline$n$ & \multicolumn{5}{|c|}{$\begin{array}{l}\text { Total inertia of global } \\
C A=3.13\end{array}$} \\
\hline Factor & Station & Season & Year & Techniq. & Sta.Tec \\
\hline between-classes CA & 0.28 & 0.14 & 0.22 & 0.11 & 0.50 \\
\hline within-classes CA & 2.85 & 2.99 & 2.63 & 3.02 & 2.63 \\
\hline
\end{tabular}

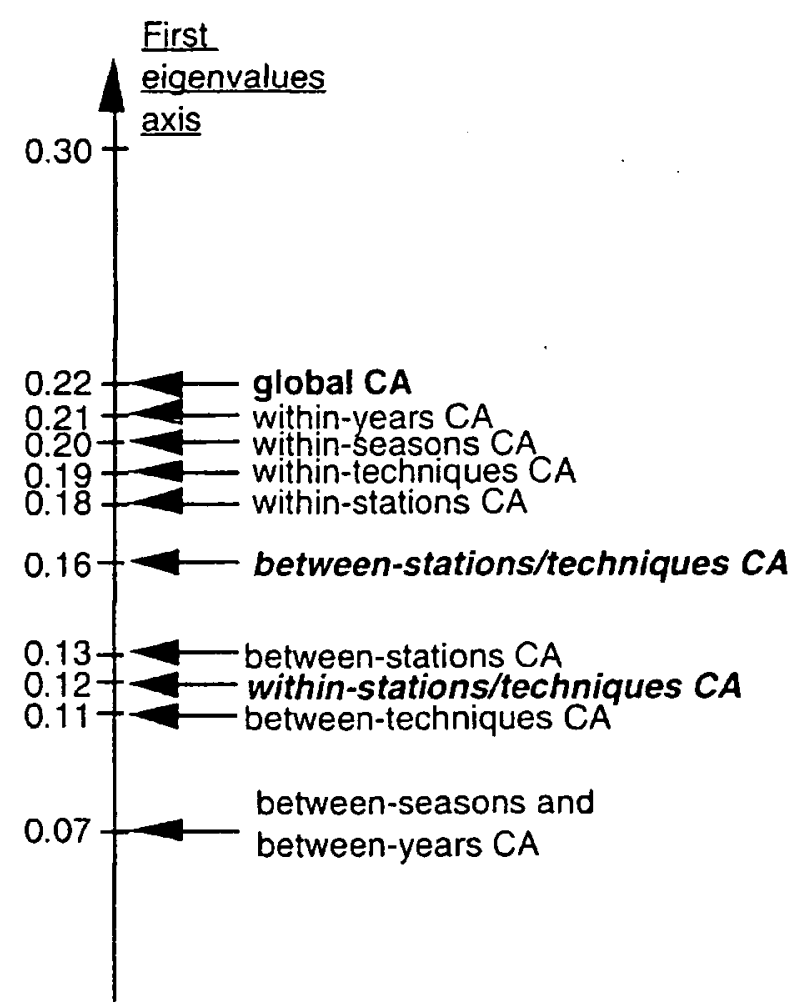

Fig. 3. Influence of spatial and temporal factors according to the between- and within-classes Principal Components Analyses, expressed by the percentage of inertia and the coordinates of the first eigenvalue of the different analyses: examples for the physicochemistry (A) and for a biological variable, the macrobenthic communities (B).

Fig. 3. Influence des facteurs spatiaux et temporels résultant des ACP inter- et intra- classes, exprimées par le pourcentage d'inertie et les coordonnées de la première valeur propre des différentes analyses : exemples de la physico-chimie (A) et d'une variable biologique, les macroinvertébrés benthiques (B).

dance $\geq 0.1 \%$ ), the mean number of individuals of one third of them was statistically different before and after the year 1989 (low discharge, high temperatures). Figure 6 showed the yearly changes of six of these species (see statistic values in Table 2). They could be separated into two groups : those with decreasing abundance (Dugesia polychroa+lugubris Schmidt and different Molluscs) and those with increasing abundance (Ecnomus tenellus Ramb.). The first ones belong to the usual benthic communities of this part of the Rhône River. They were identified as being correlated with low discharge and warm temperature by Bournaud et al. (1987). The gradual increase in discharge after the drought of 1989 had a negative influence on their communities. Inversely, the low discharge of the year 1989 allowed the installation and the expansion of Ecnomus - tenellus, a migrant potamo-lentic species probably drifting from the Saône River with the high discharges 

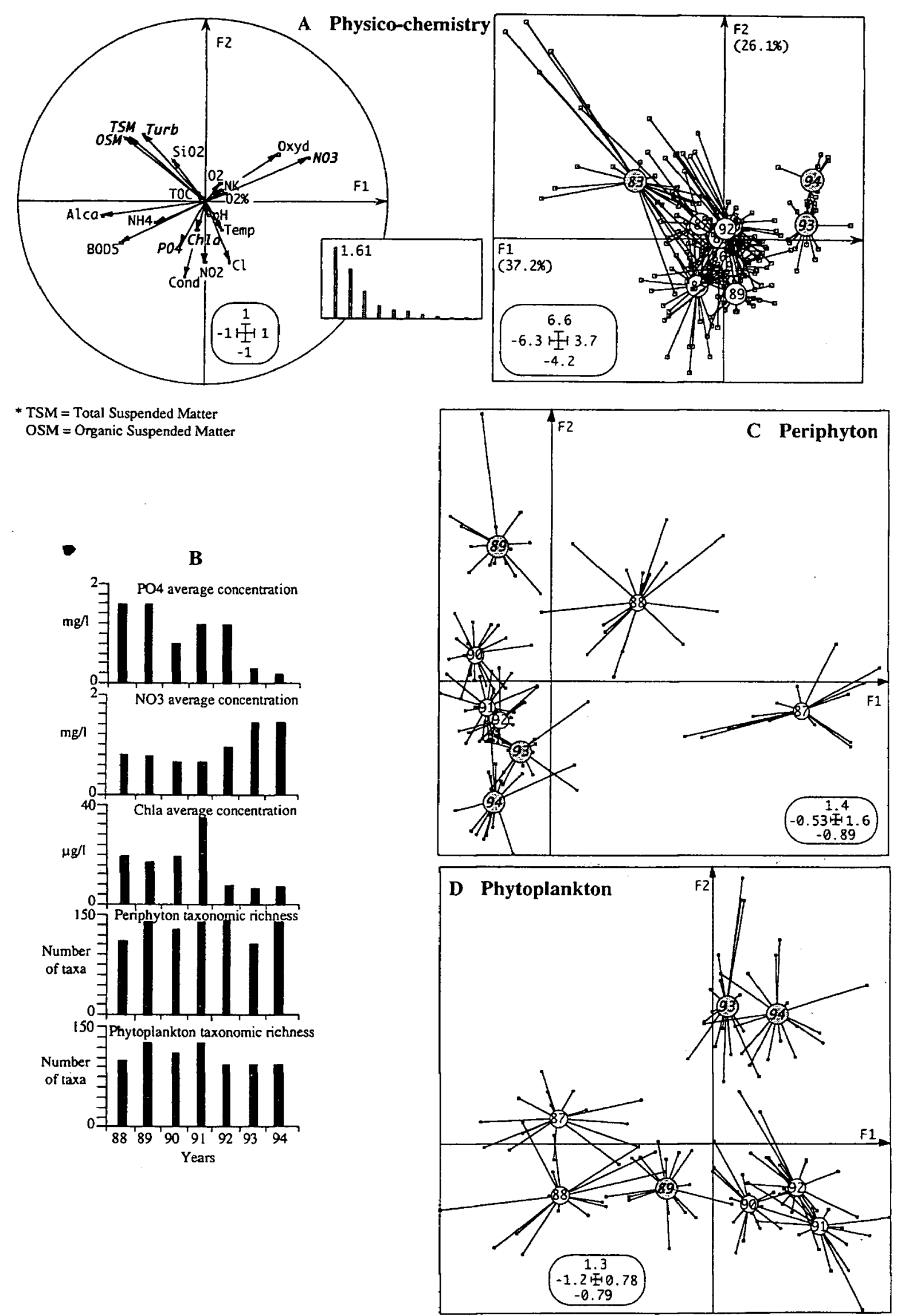

Fig. 4. Algae communitie vs physico-chemistry. Eigenvalues graph, correlation circle of the variables, and samples factorial map of the betweenyears analysis of the physico-chemistry (A) ; comparison between the yearly total taxonomic richness of the algae and the yearly average concentrations of some physico-chemical variables (B) ; samples factorial map of the between-years analysis of the periphyton (C) and of the phytoplankton (D). The circles correspond to the centre of classes and the lines to the dispersion of samples. The most significant years are in shadded circles.

Fig. 4. Etude comparée des communautés algales et de la physico-chimie. Valeurs propres, cercle de corrélation des variables et carte factorielle des relevés de l'analyse inter-années pour la physico-chimie (A) ; comparaison entre la richesse taxonomique totale annuelle des algues et les concentrations moyennes annuelles de quelques paramètres physico-chimiques (B); carte factorielle des relevés de l'analyse inter-années du périphyton (C) et du phytoplancton (D). Les cercles correspondent au centre des classes et les lignes à la dispersion des relevés. Les cercles grisés correspondent aux années particulièrement informatives. 


\section{A Macroinvertebrates}

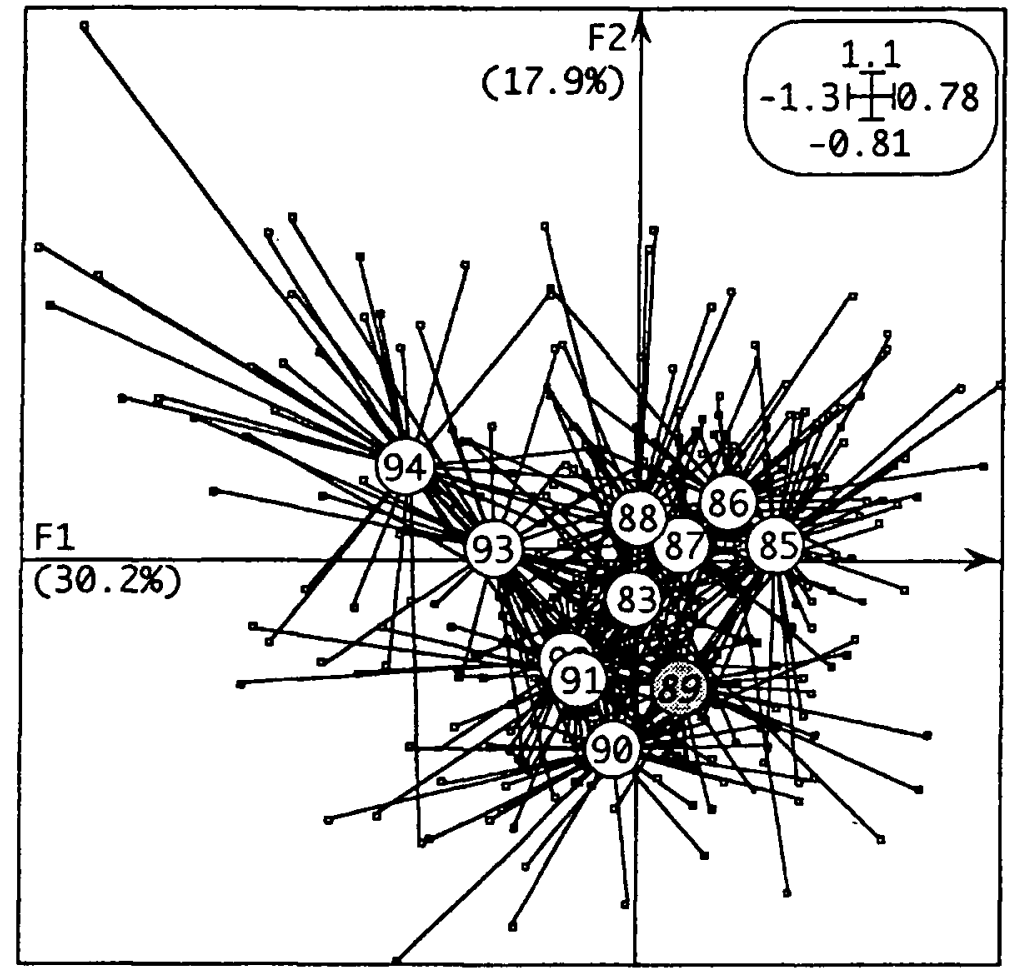

\section{B Fish fauna}

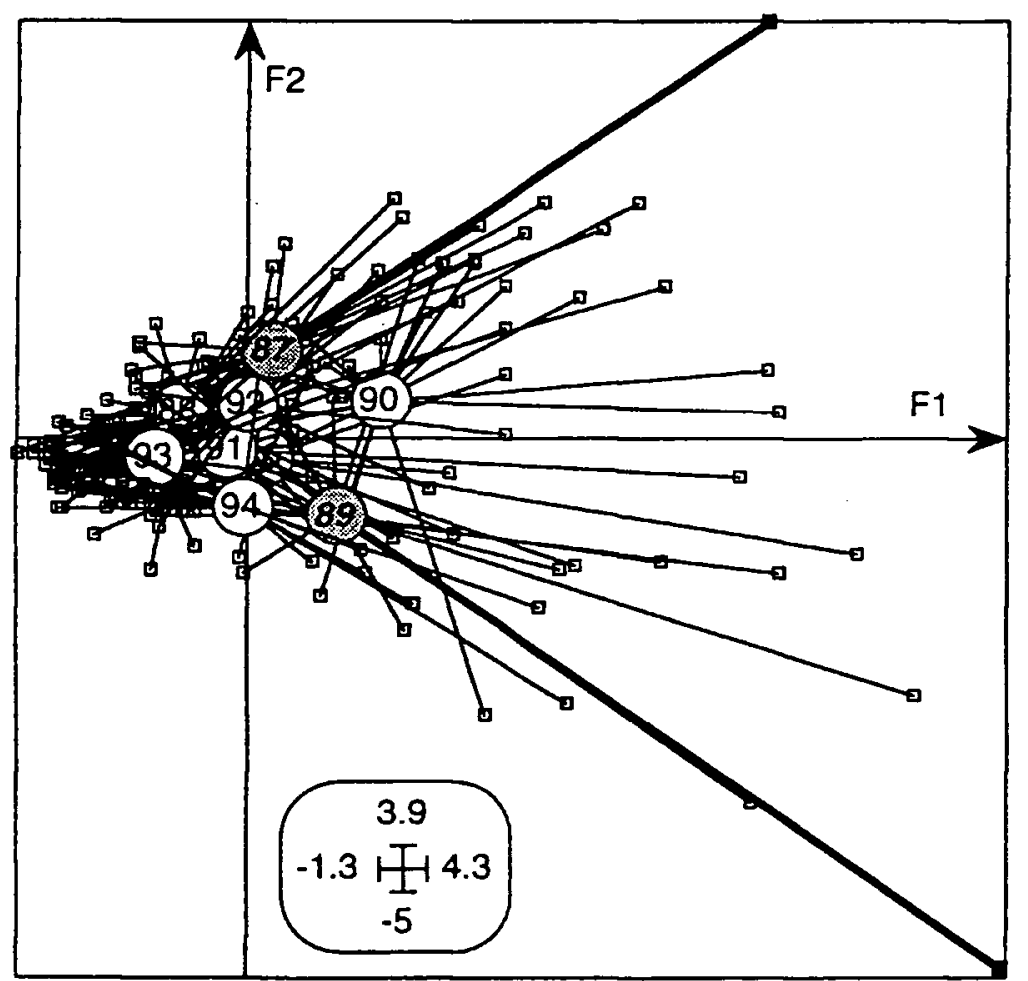

.57 Fl between-year coordinates

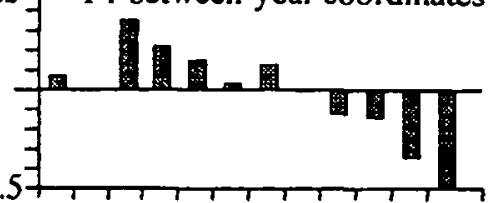

1500 Average discharge

$\mathrm{m} 3 / \mathrm{s}$
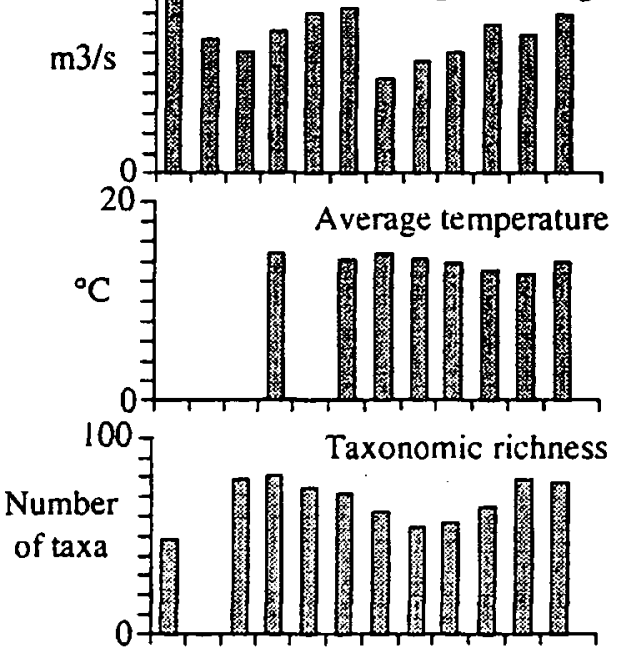

70 E. tenellus - Average abundance

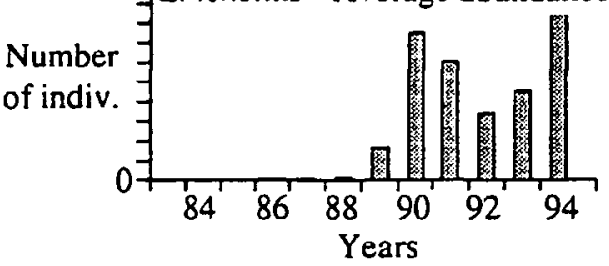

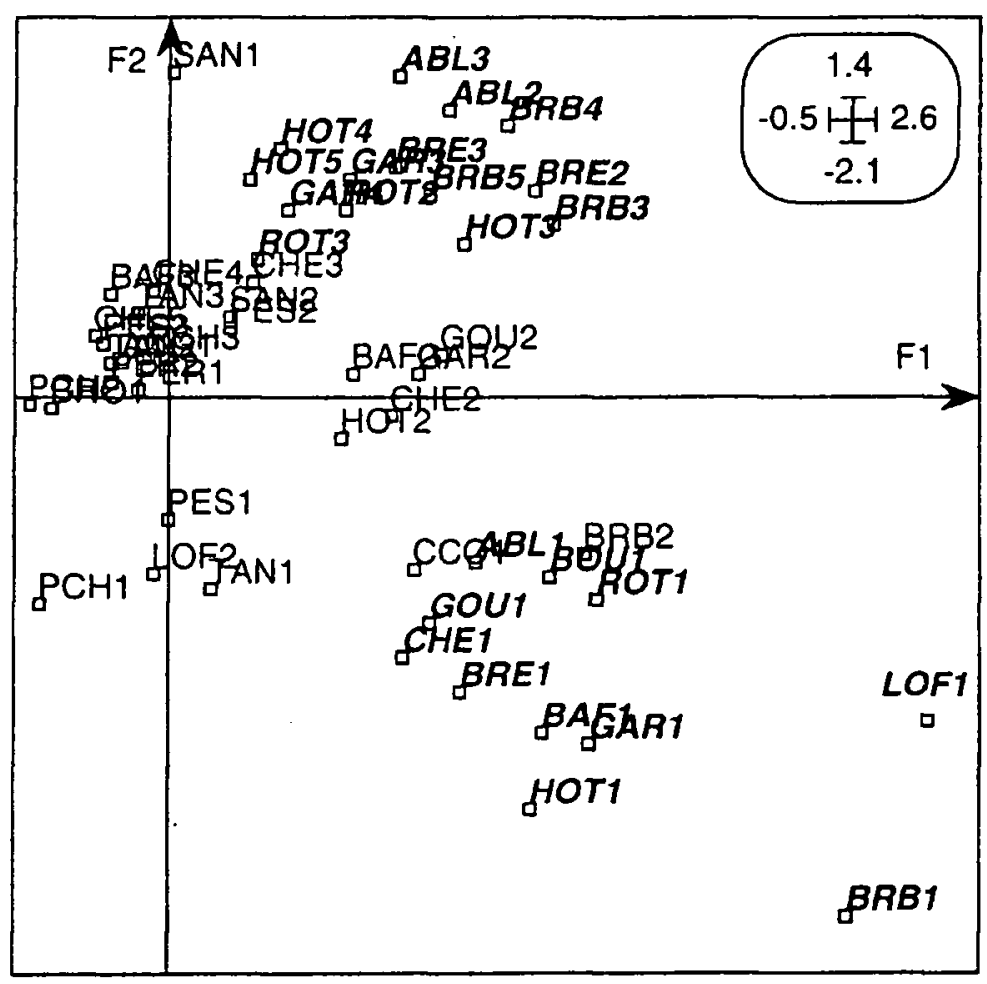

Fig. 5. Macroinvertebrate and fish communities vs hydrological and thermal conditions. Samples factorial map of the between-years analysis of the macroinvertebrates and relationship between some biological factors (F1 between-years coordinates, yearly total taxonomic richness, average abundance of the Trichoptera $E$. tenellus) and two environmental variables (yearly average discharge and temperature of the Rhône River) (A) ; samples and species factorial maps of the between-years analysis of the fish fauna separated in size classes for the dominant species (see codes in Table 1) (B). The circles correspond to the centre of classes and the lines to the dispersion of samples. The most significant years are in shadded circles.

Fig. 5. Etude comparée des peuplements de macroinvertébrés et de poissons et des conditions hydrologiques et thermiques. Carte factorielle de l'analyse inter-années pour les macoinvertébrés et relation entre différents paramètres biologiques (coordonnées interannées sur $\mathrm{F} 1$, richesse taxonomique totale annuelle, abondance moyenne du Trichoptère $E$. tenellus) et deux variables de milieu (la température et le débit moyens annuels du Rhône) (A) ; cartes factorielles des relevés et des espèces de l'analyse inter-années de l'ichtyofaune (les espèces sont distinguées par classes de taille, voir les codes des espèces et des tailles dans le Tableau 1) (B). Les cercles correspondent au centre des classes et les lignes à la dispersion des relevés. Les cercles grisés correspondent aux années particulièrement informatives. 

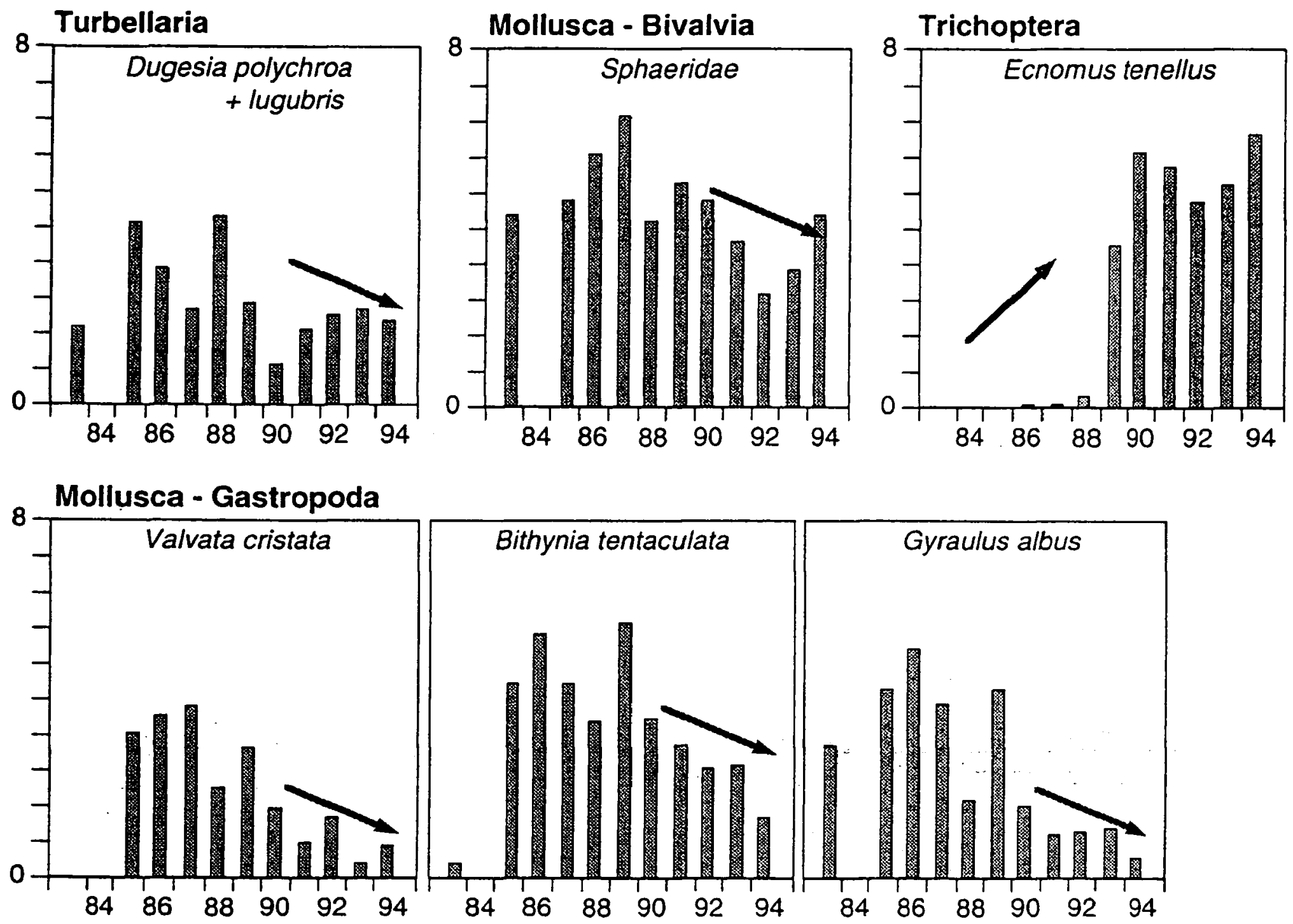

Fig. 6. Yearly changes in the average abundance per sample (number of individuals expressed as $\log 2(x+1))$ of some macroinvertebrates for which a statistically significant difference was found between the periods before and after 1989 (see Table 2).

Fig. 6. Evolution inter-annuelle de l'abondance moyenne par prélèvement (nombre d'individus exprimé en $\log 2(x+1)$ ) de quelques espèces de macroinvertébrés pour lesquelles une difference statistiquement significative est notée entre les périodes avant et après 1989 (voir Tableau 2).

Table 2. Characteristic values and t test results between yearly average abundance per sample before and after 1989 of some statistically significant $(\mathrm{P}<0.05)$ invertebrate species.

Tableau 2. Valeurs caractéristiques et résultats des tests t entre l'abondance moyenne annuelle par prélèvement avant et après 1989 pour quelques espèces de macroinvertébrés statistiquement significatives $(\mathrm{P}<0.05)$.

\begin{tabular}{lccccc}
\hline & \multicolumn{2}{c}{ Before 1989 } & \multicolumn{2}{c}{ After 1989 } & \multirow{2}{*}{ t test } \\
& Years (N) & Samples (N) & Years (N) & Samples (N) & \\
& 6 & 254 & 5 & 208 & \\
\hline & Mean & Std deviation & Mean & Std deviation & \\
Dugesia polychroa+lugubris & 8.8 & 6.9 & 2.5 & 1.0 & 1.98 \\
Valvata cristata & 7.3 & 5.1 & 1.1 & 0.7 & 2.66 \\
Bithynia tentaculata & 24.8 & 20.3 & 6.0 & 3.6 & 2.03 \\
Gyraulus albus & 16.0 & 11.5 & 1.2 & 0.6 & 2.84 \\
Sphaerium spp.+Pisidium spp. & 39.0 & 27.9 & 13.6 & 7.9 & 1.97 \\
Ecnomus tenellus & 2.1 & 4.9 & 44.4 & 17.8 & 5.64 \\
\hline
\end{tabular}


of 1987-88. It was significantly recorded at Péage-deRoussillon in 1989 (first sampling of 3 individuals in 1986). This species was found in slow potamic rivers such as the Saône or the Meuse (Tachet et al. 1988, Meurisse-Genin et al. 1987). Usseglio-Polatera (1991) described it as an eurythermic, indeed thermophilic species with preference for low current velocities.

Axis 2 of the analysis of temporal changes in the ichtyofauna mainly distinguished samples collected in autumn 1987 with positive coordinates, from those collected in summer 1989 (Fig. 5B). The distribution of species on the plot of the first two axes showed that juveniles (the first size class for most species) were rare in the autumn 1987 samples, which were mainly characterized by large-sized fish (for example bleak, codes abl2, abl3; white bream, code brb4; nase, code hot 4 ; etc.), contrasting with the high occurrence of juveniles in summer 1989 (for example roach, gar 1 ; bar- bel, baf 1 ; chub, che 1 ; common bream, bre 1 ; etc.) (Fig. 5B). The same contrast was noted at the end of the study period : 1992 was a year with a low amount of juveniles (high mean discharge and low mean water temperature, see Fig. 2), while their occurrence was high in 1994 (high summer temperature). The scarcity of the 0+ age class in 1990 was due to a biological reason, the competition with the 1+ age class of 1989 . This showed that most of the changes recorded were due to the breeding success of the dominant species.

\section{Discussion}

As far as the phytoplankton is concerned, few studies of this type were reported in the literature until the mid-1980s (Descy 1992), while studies on periphyton mainly dealt with its biomass. Hydrological conditions, both in the whole sector and in individual stations (especially stations 4 and 5), chemical properties of the water related to local or distant inputs from the catchment, plus physical properties of the water (temperature, suspended solids, etc.) had effects on the overall structure of the algal communities. This is confirmed by the key role played by year 1989 (low discharge and high temperature). This is also confirmed by the lower number of species from 1992 onwards. In fact, although nitrates, in excess compared to phosphates, were not limiting for algal growth $(r=-0.365$, between nitrate and chlorophyll a concentrations at stations 1 and 2 in the reservoir for the period 1985-1994), the decrease in phosphate may have been critical in terms of nutrient supply and may have been the cause for the reduction in phytoplankton concentrations (as measu- red by chlorophyll a) and in periphyton species richness $(r=0.523$ and $r=-0.703$ between yearly richness of periphyton and average yearly concentrations of $\mathrm{PO}_{4}$ and $\mathrm{NO}_{3}$ respectively). As nitrates were then less consumed, they accordingly occurred in larger quantities. In a similar way, Lair \& Sargos (1993) showed that, in the absence of nutrient limitation, discharge and temperature were controlling factors for the algal biomass of the river Loire, but that water quality could also be important in some cases. In the Middle Rhône, there was a constant turnover of phytoplankton communities because of the flowing character of the study area, which disrupted their spatial and temporal organization. In contrast, the periphyton seemed more typical of each sampling station. Most of the taxa were typical of eutrophic waters in the wider sense (meso-eutrophic to eutrophic), and consisted of ubiquitous opportunistic species (Fruget et al. 1999) as is often the case in nutrient-rich lowland rivers (Descy 1992, 1993, Del Giorgio et al. 1991).

The decrease in the number of macroinvertebrate taxa recorded at the end of the 1980s and early 1990s, with a partial recovery from 1992 onwards (see Fig. $5 \mathrm{~A}$ ), was probably connected to hydroclimatic factors (succession of periods of low flow and floods, thermal sequences with high and lower mean annual temperature). These observations are in accordance with the disturbance-diversity concept and tend to confirm the intermediate disturbance hypothesis (Connell 1978) : in steady conditions (years with low discharge), species richness was low (years 1989-1991) ; maximum species richness occurred when the disturbance (hydroclimatic fluctuations) was intermediate (years 1986 and 1993-1994). These events were non-biotic and stochastic and resulted in significant changes in the composition of the invertebrate fauna. In addition to the profound changes in the river environment brought about by the CNR's works which have favoured potamo-lentic species (Fruget 1991), the between-years climatic changes could explain the dynamics of macroinvertebrate communities. Thus the conditions in 1989 (low discharge and high temperature, see Fig. 2) favoured the appearance and expansion of various species such as was the case for Ecnomus tenellus (see before). Under these conditions, floods are known as the main factor controlling the structure of benthic communities (Townsend et al. 1997). New distribution and colonisation by some organisms with changes in discharge was an important process in the river's ecological functioning. In addition to the habitat changes that created suitable conditions by decreasing current velocity and increasing temperature, navigation has al- 
so favoured migrations and invasions (e.g. the crustaceans Crangonyx pseudogracilis Bousf., Gammarus roeseli Gervais and Gammarus tigrinus Sexton and the molluscs Lithoglyphus naticoïdes Pfeiffer and Corbicula fluminea Müller) (Jazdzewski 1980, Bij de Vaate 1993). The dynamics of these populations must be carefully observed, spatial and trophic competition between the new immigrants and the previously established macrobenthic populations being possible as was observed in the Rhine and the Moselle rivers (Van der Velde et al. 1994, Bachmann et al. 1997).

For the same reasons of uniformity of the communities as for the invertebrates (dominance of limnophilic Cyprinids, see Fruget 1992), the overall structure of the fish community in the study area mainly depended on hydroclimatic factors that influenced the breeding success, such as the low discharge and high temperature in 1989 and the excessive discharge in 1987. The habitat changes caused by engineering works, such as embankment and hydroelectric schemes, and lower physico-chemical quality of the water than in the Upper Rhône, have led to the disappearance of those species that have the strictest requirements for fundamental factors such as temperature and dissolved oxygen content (burbot, dace, blageon). The present fish assemblage is a relict assemblage dominated by species with broad breeding requirements (such as roach, chub, bleak, pumpkinseed and white bream which accounted for $88 \%$ of the individuals) that find conditions sufficient for them to complete their life cycle. The size class distributions of the most abundant species show that recruitment occurred normally for these species during the study period (Fruget et al. 1999). Most fish species forming the communities in large rivers are long-lived species whose life-history traits (fecundity, egg size, etc.) adapt them for survival in environments with broad natural hydrological variations. Long-term studies are therefore the best means for separating short-term events, such as the effects of a flood, from events whose effects are felt over a longer period (lasting problems of recruitment in a given species).

\section{Conclusion}

The physical, chemical and biological characteristics of the Middle Rhône are mainly the result of artificial changes in the river and in its catchment (Fruget 1992). From a biological point of view the system is shifting from an epipotamic river (high flow velocities, coarse granulometry) with rheophilic insect species (especially Ephemeroptera and Trichoptera), towards a slow potamic type, with communities composed of ubiquitous and resistant species and a few more sensitive, but relict, species. From a physico-chemical point of view, its large size, and the inertia of the water mass to external inputs, allows the environment to assimilate large inorganic and organic loads.

Discharge and temperature seem to be the major events controlling the physico-chemical and biological dynamics of the Péage-de-Roussillon area (in terms of between-years variations in physico-chemical variables, species richness, diversity and abundance of algae and animals). This is confirmed whatever descriptor is considered : change in abundance of some taxa with low flow rates and warm period preferences, appearence and increase of a potamo-lentic and thermophilic Trichoptera species or high occurrence of juvenile fish after the low discharge and the high temperature of the year 1989. Variations in nutrient input played a secondary role in controlling changes in some communities (particularly the periphyton).

Within this general framework, it seems difficult to distinguish low-level anthropogenic disturbances from normal variations imposed by long-term natural cycles (Schindler 1987). In our case, the effect of the warm water discharge from St-Alban power plant appears to be difficult to discern in an environment that has already been profoundly modified, and that has already adapted to previous changes. At present, it is still the previous changes, such as the CNR's works, that control the system's physical and biological characteristics. In such a situation, long-term studies are the only means of discerning any effect, especially as the effects on the fauna and flora are likely to be moderate or even insignificant and liable to be masked by changes that took place before the power plant was operated.

Magnusson (1990) warned of the risks of false interpretations of phenomena that are only observed for short periods. Similarly, Persat (1991) considered that the conventional spatio-temporal context in which most studies on rivers are conducted is fundamentally too short. Such studies require information on all of the components of the aquatic system, and obtaining such information requires continuous monitoring in time and space (Lair et al. 1996). This is one of the main concerns in ecological research (Elliott 1990, Likens 1989, Wiens et al. 1986). In such cases, the study of changes in fluvial hydrosystems and of the dynamics of their communities demands continuous observation and data collection that only medium- or long-term studies can provide, implying the setting up of ecolo- 
gical monitoring centres for the natural environment such as the long-term ecological research (LTER) sites in the United States (Magnusson 1990).

The fundamental value of such research largely depends on the methodology used and the spatio-temporal sampling strategy chosen. The repetitive nature of this sampling provides information on the functional dynamics and can allow lessons to be drawn in the field of applied ecology (Bellan \& Bourcier 1990, Reish \& Bellan 1995). In return, this applied approach to environmental problems greatly contributes to our knowledge of how the ecosystems studied function.

\section{Acknowledgements}

This study was funded by EDF as part of the hydrobiological monitoring of the Rhône in the vicinity of the St-Alban - St-Maurice power plant. The authors thank Mr Etienne Coatleven (EDF St-Alban) for the interest shown in this monitoring and for his help in supplying data, especially on temperature records, and Prof. Eric Pattee for English corrections of the final draft of this manuscript. This monitoring also required the cooperation of many colleagues, both in the field and in the laboratory. We thank them all.

\section{References}

Bachmann V., Usseglio-Polatera P., Cegielka E., Wagner P., Poinsaint J.F. \& Moreteau, J.C. 1997. - Premières observations sur la coexistence de Dreissena polymorpha, Corophium curvispinum et Corbicula spp. dans la rivière Moselle. Bull. Fr. Pêche Piscic., 344/345 : 373-384.

Bellan G. \& Bourcier M. 1990. — Les enseignements d'une étude sur dix ans (1976-1986) des peuplements au large d'un émissaire d'eaux usées : Marseille-Cortiou. Cah. Biol. Mar., 31 : 225 - 249.

Bij de Vaate A. 1993. - Exotic and aquatic macroinvertebrates in the Dutch part of the River Rhine : causes and effects. In : Van Dijk G.M. \& Marteijn E.C.L. (eds), Ecological rehabilitation of the rivers Rhine and Meuse, Institute for Inland Water Management and Waste Water Treatment, Lelystad : 27-29.

Bournaud M. \& Amoros C. 1984. - Des indicateurs biologiques aux descripteurs de fonctionnement : quelques exemples dans un système fluvial. Bull. Ecol., 15 (1) : 57-66.

Bournaud M., Tachet H. \& Roux A.L. 1987. - The effects of seasonal and hydrological influences on the macroinvertebrates of the Rhône River, France. II. Ecological aspects. Arch. Hydrobiol., Suppl. $76(1-2): 25-51$.

Connell J.H. 1978. - Diversity in tropical rain forests and coral reefs. Science, $199:$ 1302-1310.

Del Giorgio P.A., Vinocur A.L., Lombardo R.J. \& Tell H.G. 1991. - Progressive changes in the structure and dynamics of the phytoplankton community along a pollution gradient in a lowland river - a multivariate approach. Hydrobiologia, $224:$ 129-154.

Descy J.P. 1993. - Ecology of the phytoplankton of the River Moselle : effects of disturbances on community structure and diversity. Hydrobiologia, $249: 111-116$.

Descy J.P. 1992. - Eutrophication in the River Meuse. In : Sutcliffe D.W. \& Jones J.G. (Eds), Eutrophication: research and application to water supply. Freshwater Biological Association, Ambleside (G.B.) : 132-142.
Dolédec S. \& Chessel D. 1989 - Rythmes saisonniers et composantes stationnelles en milieu aquatique. II. Prise en compte et élimination d'effets dans un tableau faunistique. Acta Oecol., Oecol. Gener., 10 (3) : 207-232.

Dolédec S., Chessel D. \& Olivier J.M. 1995. - L'analyse des correspondances décentrée : application aux peuplements ichtyologiques du Haut-Rhône. Bull. Fr. Pêche Piscic., 336 : 29-40.

Dynesius M. \& Nilsson C. 1994. - Fragmentation and flow regulation of river systems in the northern third of the world. Science, 266, 753-762.

Elliott J.M. 1990. - The need for long-term investigations in ecology and the contribution of the Freshwater Biological Association. Freshwater Biol., 23 : 1-5.

Elliott J.M., Drake C.M. \& Tullett P.A. 1980. - The choice of a suitable sampler for benthic macroinvertebrates in deep rivers. Pollut. Rep. Dep. Environ., 8 : 36-44.

Fruget J.F. 1991. - The impact of river regulation on the lotic macroinvertebrate communities of the Lower Rhône, France. Regul. Rivers, 6 (4) : 241-255.

Fruget J.F. 1992. - Ecology of the Lower Rhône following 200 years of human influence: a review. Regul. Rivers. 7 (3) : 233-246.

Fruget J.F. 1994. - Invertebrate communities in a regulated floodplain of the Middle Rhône River. Verh. Internat. Verein. Limnol., 25 (3) : 1549-1554.

Fruget J.F. \& Michelot J.L. 1997. — Dérives écologiques et gestion du milieu fluvial thodanien. Rev. Géogr. Lyon, 72 (1) : 35-48.

Fruget J.F., Centofanti M., Dessaix J., Olivier J.M., Druart J.C. \& Martinez P.J. 1999. - Synthèse des dix premières années de suivi hydrobiologique du Rhône au niveau de la centrale nucléaire de Saint-Alban. Hydroécol. Appl., 11 (1-2) : 29-69.

Jazdzewski K. 1980. - Range extensions of some gammaridean species in European inland water caused by human activity. Crustaceana, suppl. $6: 84-107$.

Johnson B.L., Richardson W.B. \& Naimo T.J. 1995. — Past, present and future concepts in large river ecology. BioScience, 45 (3) : 134-141.

Khalanski M. \& Gras R. 1996. - Rejets thermiques en rivières et hydrobiologie. Un aperçu sur l'expérience française. La Houille Blanche, 5 : 13-18.

Lair N. \& Sargos D. 1993. - A 10 years study in the middle course of the River Loire. I - Patterns of change in hydrological, physical and chemical variables at the sites of the nuclear power plants, in relation to algal biomass. Hydroécol. Appl., 5 (1) : 1-27.

Lair N., Sargos D. \& Reyes-Marchant P. 1996. - Synthèse des études hydrobiologiques réalisées en Loire moyenne au niveau du site nucléaire de Dampierre-en-Burly (France). Hydroécol. Appl., $8(1-2): 35-84$.

Likens G.E. 1989. - Long-term studies in ecology. Approaches and alternatives, Springer Verlag, Berlin : $214 \mathrm{p}$

Lorenzen H 1967. - Determination of chloropyll and pheopigments : spectrophotometric equations. Limnol. Oceanog. 12, 343-346.

Magnuson J.J. 1990. — Long-term ecological research and the invisible present. BioScience, 40 (7) : 495-501.

Meurisse-Genin M., Reydams-Detollenaere A., Stroot P. \& Micha J.C. 1987. — Les macroinvertébrés benthiques de la Meuse belge : bilan des cinq années de recherche (1980 à 1984). Arch. Hydrobiol. , 109 (1) : 67-88.

Michelot J.L. 1983. — Evolution des paysages fluviaux de la Vallée du Rhône dans le secteur du Péage-de-Roussillon. Rev. Géogr. Lyon, 58 (4) : 307-322.

Nelva A., Persat H. \& Chessel D. 1979. - Une nouvelle méthode d'étude des prélévements ichtyologiques dans les grands cours d'eau par échantillonnage ponctuel d'abondance. C.R. Acad. Sci. Paris, 289 : 1295-1298. 
Parsons T.R. \& Strickland J.D.H. 1963. - Discussion of spectrophotometric determination of marine-plant pigments, with revised equations for ascertaining chlorophyllls and carotenoids. $J$. Mar. Res., 21 (3) : 155-163.

Persat H. 1991. - Espace et temps, pierres d'achoppement des études d'impact en milieu fluvial. Bull. Ecol., 22 (1) : 203-212.

Persat H. \& Copp G.H. 1990. - Electric fishing and point abundance sampling for the ichtyology of large rivers. In : Cowx I.G. (Ed.), Developments in electric fishing. Fishing News Books, Blackwell, Cambridge, 27 : 197-209.

Persat H. \& Olivier J.M. 1991. - The point abundance sampling, a fishing strategy for large rivers : short presentation of the concept, its appliance and some results. In : Penaz M. (ed.), Biological monitoring of large rivers, Czechoslovak Academy of Sciences, $\mathrm{Br}$ no \& Slovak Academy of Sciences, Bratislava Publishers : 104-113.

Persat H., Olivier J.M. \& Bravard J.P. 1995. - Stream and riparian management of large braided mid-European rivers, and consequences for fish. In : Armantrout N.B. (ed.), Condition of the world's aquatic habitats. Proceedings of the World Fisheries Congress, Theme 1, Oxford \& IBH Publishing Co. Pvt. Ltd., New Delhi : 139-169.

Petts G.E., Möller H. \& Roux A.L. 1989. - Historical change of large alluvial rivers in Western Europe. Wiley, Chichester : $355 \mathrm{p}$.

Pickett S.T.A., Kolasa J., Armesto J.J. \& Collins S.L. 1989. - The ecological concept of disturbance and its expression at various hierarchical levels. Oikos, 54 (2) : 129-136.

Reish D.J. \& Bellan G. 1995. - The long-term effects of municipal discharges from urban areas on the marine environment : a review. In : Bellan D., Bonin G. \& Emig C. (eds), Functioning and dynamics of natural and perturbed ecosystems. Tec \& Doc - Lavoisier, Paris : 701- 743.

Reys J.P. \& Salvat B. 1971. — L'échantillonnage de la macrofaune des sédiments meubles marins. In : Lamotte M. \& Bourlière F.,
Problèmes d'écologie : l'échantillonnage des peuplements animaux des milieux aquatiques. Masson, Paris : 185-242.

Schindler D.W. 1987. - Detecting ecosystem responses to anthropogenic stress. Can. J. Fish. Aquat. Sci., 44:6-25.

Statzner B. \& Higler B. 1986. - Stream hydraulics as a major determinant of benthic invertebrate zonation patterns. Freshwater Biol., $16: 127-139$

Tachet H., Gaschignard-Fossati O., Cellot B. \& Berly A. 1988. — Le macrobenthos de la Saône. Ann. Limnol., 24 (1): 83-100.

Thioulouse J., Chessel D., Dolédec S. \& Olivier J.M. 1997. — ADE4: a multivariate analysis and graphical display software. Statistics and Computing, $7: 75-83$.

Townsend C.R. 1989. - The patch dynamic concept of stream community ecology. J. North Am. Benthol. Soc., $8: 36-50$.

Townsend C.R., Scarsbrook M.R. \& Dolédec S. 1997. - The intermediate disturbance hypothesis, refugia, and biodiversity in streams. Limnol. Oceanogr., 42 (5) : 938-949.

Usseglio-Polatera P. 1991. - Représentation graphique synthétique de la signification écologique d'un peuplement. Application aux macroinvertébrés du Rhône à Lyon. Bull. Ecol., 22 (1) : 195-202.

Van der Velde G., Paffen B.G.P. \& Van den Brink F.W.B. 1994. Decline of zebra mussel populations in the Rhine : competition between two mass invaders (Dreissena polymorpha and Coro phium curvispinum). Naturwiss., 81 : 32-34.

Ward J.V. \& Stanford J.A. 1983. - The intermediate-disturbance hypothesis : an explanation for biotic diversity patterns in lotic ecosystems. In : Fontaine T.D. \& Bartell S.M. (eds), Dynamics of lotic ecosystems. Ann Arbor Science Publ., Ann Arbor : 347-356.

Wiens J.A., Addicott J.F., Case T.J. \& Diamond J. 1986. - Overview : the importance of spatial and temporal scale in ecological investigations. In : Diamond J. \& Case T.J. (eds), Community ecology. Harper \& Row, New-York : 145-153. 